\title{
Studies of Molten-Salt-Catalysed \\ Coal Gasification
}

Final Technical Report.

DOE Grant \# DE-FG21-78ET13382

\author{
H. Saltsburg \\ Department of Chemical Engineering \\ University of Rochester
}

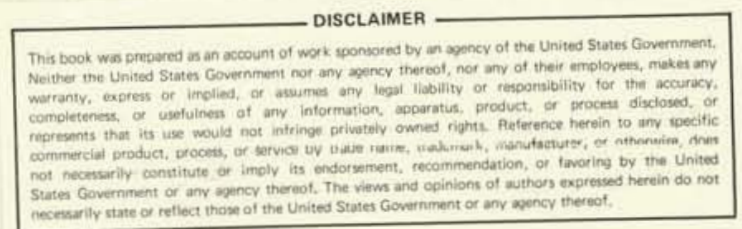

\section{MoTice}

PORTIONS OF THIS REPORT ARE HELEAIGLE,"

it has been reprociuced from the best avaliable copy to permit the broadest possibie avallabtility. 


\section{DISCLAIMER}

This report was prepared as an account of work sponsored by an agency of the United States Government. Neither the United States Government nor any agency Thereof, nor any of their employees, makes any warranty, express or implied, or assumes any legal liability or responsibility for the accuracy, completeness, or usefulness of any information, apparatus, product, or process disclosed, or represents that its use would not infringe privately owned rights. Reference herein to any specific commercial product, process, or service by trade name, trademark, manufacturer, or otherwise does not necessarily constitute or imply its endorsement, recommendation, or favoring by the United States Government or any agency thereof. The views and opinions of authors expressed herein do not necessarily state or reflect those of the United States Government or any agency thereof. 


\section{DISCLAIMER}

Portions of this document may be illegible in electronic image products. Images are produced from the best available original document. 


\section{Introduction}

The research which was carried out was an investigation into the mechansim of the well-known and.widely-reported alkali metal carbonate catalysed reaction of carboneaceous materials with $\mathrm{CO}_{2}$ and $\mathrm{H}_{2} \mathrm{O}$.

The basic premise of the proposal was that the particular alkali metal ion was unimportant but rather it was $\mathrm{CO}_{3}^{=}=10 \mathrm{n} \cdot$ which was relevant. Hence, it was desirable to evaluate the concentration dependence of the gasification reaction upon $\left[\mathrm{CO}_{3}^{\overline{0}}\right]$ since the stoichiometric reaction known as the Boudouard reaction ${ }^{1}$

$$
\mathrm{C}+\mathrm{CO}_{2} \stackrel{\rightleftarrows}{\rightleftarrows} 2 \mathrm{CO}
$$

could as well be expressed in terms involving $\mathrm{CO}_{3}^{=}$:

$$
\mathrm{CO}_{3}^{=}+\mathrm{C} \rightleftharpoons 2 \mathrm{CO}+\mathrm{O}=
$$

This must be particularly important since the overall gasification process proceeds both with solid catalyst (i.e.: when it is botow the carbonate m.p.j as well as when the catalyst is molten and ionic species are present. The use of the molten salt for study allows one to capitalize on a solid-state electrolyte-based oxyen sensor to investigate the thermodyamic activity of $0=$ 
during the reaction and hence infer $\mathrm{CO}_{3}^{=}$dependence even in. non pure carbonate systems. ${ }^{2}$

Two molten salt systems were proposed for study with $\mathrm{CO}_{2}$ and $\mathrm{H}_{2} \mathrm{O}:$

A. The pure carbonate melts and

B. Melts in which $\mathrm{CO}_{3}^{=}$could be produced at lower concentrations relative to pure melt.

The pure carbonate melts included the appropriate binary and ternary eutectic mixtures to permit a study of lower temperature molten materials; the solvent system was the LiCl-KCl eutectic in which $\mathrm{CO}_{3}^{=}$could be dissolved as a slightly stable complex and in which for example $\mathrm{S}_{2} \mathrm{O}_{2}=\mathrm{B}_{2} \mathrm{O}_{3}$ and $\mathrm{V}_{2} \mathrm{O}_{5}$ could be dissolved establishing as liell a variety of buffered $0=$ concentrations. These 0 equilibria would be coupled with control of $\mathrm{CO}_{2}$ pressure so that the equilibrium $\mathrm{CO}_{3} \rightleftharpoons \mathrm{CO}_{2}+\mathrm{o}^{=}$would allow $\mathrm{CO}_{3}$ to be fixed for given $\mathrm{CO}_{2}$ pressure.

\section{Results}

The solid state electrolyte sensor system utilizing gold electrodes lias found to be a suitable oxygen sensor for use in pure carbonate melts. Gold film electrodes were unstable but a heavy gold vire contact proved stable in molten carbonates. The oxygen activity has been measured in pure Na ${ }_{2} \mathrm{Co}_{3}\left(\mathrm{mp} 858^{\circ} \mathrm{C}\right.$ in 
the $58 \% \mathrm{Na}, 42 \% \mathrm{~K}$ binary cutectic (mp 710) and in the $43 \% \mathrm{Li}$, $31 \% \mathrm{Na}$ $25 \% \mathrm{~K}$ ternary cutcctic $\left(\mathrm{mp} 397^{\circ} \mathrm{C}\right)$. In each melt the measured value of $\mathrm{O}^{=}$is described quantitatively by the partial pressure of $\mathrm{O}_{2}$ which would be in equilibrium with the $\mathrm{O}^{=}$in the melt. These pressure values are in the range of .01 to $.05 \mathrm{~atm}$ for all three melt systems. The temperature dependence is not strong. More importantly, however, the value of $\mathrm{P}_{2}$ does not seem to follow the equilibrium behavior reported to hold in melts and usually expressed as

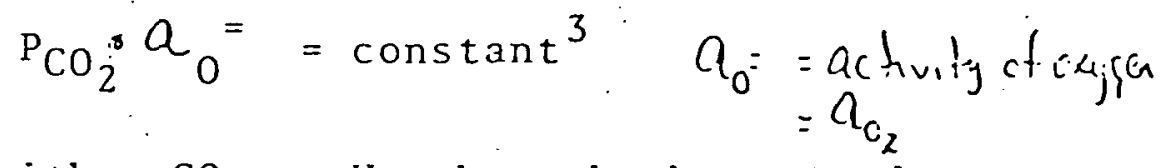

since the passage of either $\mathrm{CO}_{2}$ or He through the melt does not significantly alter the measured $\mathrm{Q}_{2}$.

When carbonaceous material is introduced into these single component and binary eutectic melts through lhich $\mathrm{CO}_{2}$ is passing, there is an imediate and very large lousose in the oxyen activity (Fig. 1). These initial studics bere carricd out in an open $\mathrm{Al}_{2} \mathrm{O}_{3}$ crucible but samples of the gascous atmosphere above the melt liere aspirated to a gas chromatograph and show the presence of CO. The lower melting ternary system was studied over the range $500^{\circ}$ to $700^{\circ} \mathrm{C}$. There is a significant difference in behavior as a function of temperature. At $500^{\circ} \mathrm{C}$ the presence of carbon has little effect on $Q_{O_{2}}$ measured and no co could be detected. At $600^{\circ} \mathrm{C}$, the oxygen activity began to decreasc but only the change seen at $700^{\circ} \mathrm{C}$ was consistent with the other pure nẹts. 
A cuantitative gasification rate measurencnt lias not possible in the open crucible but a closed tank reactor has becn built and tested, although no extensive data were obtained.

The removal of the solid carbon from the carbonate melts produced a strikingly slow return of the oxygen activity to its initial value (compared with the speed of the initial decrease). The rate of the return was a function of the nature of the gas used to purge the melt; He caused a more rapid return than $\mathrm{CO}_{2}$ and with no purge the return was very slow. An example for the binary eutectic is shown in Fig. 1 .

It should be noted that the oxygen activity in the melt during reaction, although quite low, was still orders of magnitude larger than that characteristic of the gascous equilibrium betlicen $\mathrm{CO}, \mathrm{CO}_{2}, \mathrm{C}$ and oxygen.

It has been pointed out that koH is nearly as cfrective a

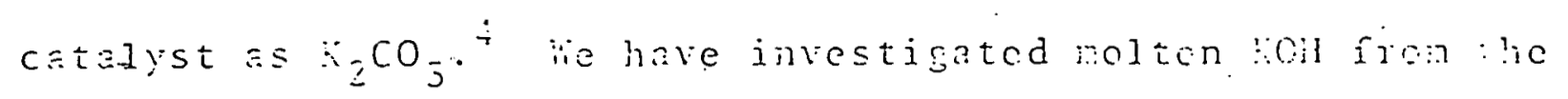
rielting point $\left(400^{\circ} \mathrm{C}\right)$ to $700^{\circ} \mathrm{C}$. Even with a $\mathrm{CO}_{2}$ purge the oxyson activity remained equilibrated with air (over periods of hours). end over the entire temperature range the introduction of carbonaccous material had no effect on the activity. Additionally, no co lias detected using the aspirator procedure.

Tests of the $\mathrm{H}_{2} \mathrm{O}$ driven reaction in an open crucible proved to be unreproducible and liere abandoned until the closed reactor lias available. 
A study of the $\mathrm{LiCl}-\mathrm{KCl}$ eutectic (mp $352^{\circ} \mathrm{C}$ ) with $28 \mathrm{Li}_{2} \mathrm{CO}_{3}$ dissolved in it showed that the relatively high oxygen activity in the range $400-600^{\circ} \mathrm{C}$ was sharply lowered by introduction of carbonaceous material. Without carbonate in the melt, no effect of carbon on the $\mathrm{O}^{=}$activity was observed.

A controlled atmosphere fused salt reactor has been built and tested. The analysis of the product and effluent streams is with the gas.chromatograph, the sampling value for which is: "on line" to the reactor. (Fig. 2) A flow system has been set up to permit a variety of gases to be introduced into the melt (Fig. 3). The-electrode is a dipping sensor and is mechanically stable when the melt cools and solidifies. The reactor is equipped with a carbon introduction port to allow solid pieces to be inserted and renored from the melt or to allow a powder slurry reaction to be studied (to increase the available surface area).

\section{Discussion}

These observations enable one to distinguish between several mechanistic proposals for the catalytic process and to discuss the role of $k 011$ in the process. 
There are essentially two types of mechanisms suggested for the reaction of $\mathrm{C}$ with $\mathrm{CO}_{2} \cdot{ }^{5}$ The first is based upon the observed volatilization of alkali metal from carbonate catalysed systems and proposes that a possible mechanism consists of the 3-step sequence

$$
\begin{aligned}
\mathrm{M}_{2} \mathrm{CO}_{3}+2 \mathrm{C} & =2 \mathrm{M}+3 \mathrm{CO} \\
2 \mathrm{M}+\mathrm{CO}_{2} & =\mathrm{M}_{2} \mathrm{O}+\mathrm{CO} \\
\mathrm{M}_{2} \mathrm{O}+\mathrm{CO}_{2} & =\mathrm{M}_{2} \mathrm{CO}_{3}
\end{aligned}
$$

with the first step being rate limiting. (A significant loss. of free metal from the catalyst is less likely in a molten salt as $M$ is typically soluble.) If reaction (1) does occur then the large observed decrease in oxygen activity liould have to be associated with consumption of $0=$ by $M$ via a reaction such as $\mathrm{M}_{2} \mathrm{O} \rightarrow 2 \mathrm{M}^{+}+\mathrm{O}^{=}$. With (I) rate limiting, $\mathrm{N}_{2} \mathrm{O}$ would be equilihrated. The inconsistency becomes clear when the second class of proposals which are "electrochemical" in nature are discussed. The first, that of Jalan Rao $^{5}$, is a version of the first proposal:

$$
\begin{gathered}
\mathrm{CO}_{3}=2 \mathrm{C}=3 \mathrm{CO}(\mathrm{g})+2 \mathrm{e} \\
2 \mathrm{M}^{+}+\mathrm{CO}_{2}(\mathrm{~g})+2 \mathrm{e}=\mathrm{M}_{2} \mathrm{O}(\mathrm{s})+\mathrm{CO}(\mathrm{g}) \\
\therefore \mathrm{M}_{2} \mathrm{O}+\mathrm{CO}_{2}=\mathrm{M}_{2} \mathrm{CO}_{3}
\end{gathered}
$$

In this case tio sites are required so that the redox couple can be formed. The observation that oxygen activity falls with reaction (and does not fall when no co production occurs) is not obviously consistent "ith this proposal. This can be sech for 
if one cliainates the netal ion in this mechanism, the second and thịd stcps may be iritten in the form

$$
\begin{aligned}
& \mathrm{CO}_{2}+2 \mathrm{e} \rightarrow \mathrm{O}=+\mathrm{CO} \\
& \mathrm{O}+\mathrm{CO}_{2} \rightarrow \mathrm{CO}_{3}^{=}
\end{aligned}
$$

The process represented by(5) has been carried out by Lorenz \& Janzby imposition of an appropriate potential in an electrochemical cell but rould not lead to a loss of $0^{=}$activity in the melt. Further, it is not clear that (6) actually occurs.

The third proposal (due to Wagner ${ }^{6}$ ) (which is consistent with our proposal) is also electrochenical but does not involve the netal ion:

$$
\begin{gathered}
\mathrm{CO}_{3}{ }^{+}+2 \mathrm{e}=\mathrm{CO}(\mathrm{g})+20= \\
\mathrm{C}+\mathrm{O}^{=}=\mathrm{co}(\mathrm{ad})+2 \mathrm{c} \\
\mathrm{co}(\mathrm{ad})=\mathrm{CO}(\mathrm{g}) .
\end{gathered}
$$

Tinis mechanism allows for the rapid reduction of $O=$ when $C$ is introduced and CO is produced. A lack of CO production implies no reduction in $\mathrm{O}^{=}$, as observed. It suggests also that KoH would intrinsically not be catalytically active with $\mathrm{CO}_{2}$ but depends upon conversion to $\mathrm{K}_{2} \mathrm{CO}_{3}$ to become effective.

The notion of adsorbed CO (on C) and a subsequent release of CO docs not cxplain the very slow return of 0 activity to its initial value prior to reaction, nor the differences in rate obscricd beticen a $1 \mathrm{le}$ and $\mathrm{CO}_{2}$ purge. 'It is possible that $\mathrm{CO}$ is being purged out of the melt and the nass transport across 
the purge bubble boundary domaintes the rate rather than a reversal of a chemical equilibrium. A crude estimate of the ratio of the rate of diffusion into the He bubble relative to a $\mathrm{CO}_{2}$ bubble suggests a factor of 3 to 4 which is larger than that observed. Only a careful chemical analysis will enable one to detect $C O$ in the purge gas. This was not possible using the aspiration technique. Thus, the observation of the very low 0 activity during reaction does not seem to be consistent with metal cation involvement. The liagner type mechanism seems to. be more appropriate. The argument that $\mathrm{Li}_{2} \mathrm{CO}_{3}$ is a more effective catalyst than $\mathrm{K}_{2} \mathrm{CO}_{3}$ must be in the main a reflection of the lower m.p. (Fig. 18. ref.l.) and lower temperature for liquid film. formation. The observation that $\mathrm{KOH}$ is as effective as $\mathrm{K}_{2} \mathrm{CO}_{3}$ is not borne out by molten salt studies. In an impregnated or mecharically mixed system the rate of conversion of koll to $\mathrm{K}_{2} \mathrm{CO}_{3}$ by $\mathrm{CO}_{2}$ is adequate to mask any induction period but in the melt system, the total conversion to $\mathrm{K}_{2} \mathrm{CO}_{3}$ by bubbling $\mathrm{CO}_{2}$ through the melt was negligible for a period of several hours. Hence, it was not possible to produce $\mathrm{K}_{2} \mathrm{CO}_{3}$ in significant quantities and hence no $O^{=}$activity change was observed when carbon was introduced into the melt. (The binary eutectic at its m.p., $710^{\circ} \mathrm{C}$, exhibits a very great decrease when carbon is introduced.)

The fact that $\mathrm{Na}_{2} \mathrm{CO}_{3}$ decompose to $\mathrm{Na}_{2} \mathrm{O}$ and $\mathrm{CO}_{2}$ at the m.p: could explain a large $\mathrm{O}^{=}$activity in pure melts (via $\mathrm{Na}_{2} \mathrm{O} \rightleftharpoons 2 \mathrm{Na}^{+}+\mathrm{O}^{=}$) but wher $\mathrm{CO}_{2}$ is present the mechanisms which propose metal cation involvement consume $x^{t}$ and hence are not likely to decrease $0=$ 
The ternary entectic has $43 \% \mathrm{Li}_{2} \mathrm{CO}_{3}$ and jet it is not cffective catlytically at temperatures significantly lower than that of thic binary cutectic. This too suggests that it is not the Li salt per se but the ability to produce $\mathrm{CO}_{3}$ in a $1 \mathrm{iquuid}$ film (i.e. a. lover m.p.) which accounts for its superior behavior. The data of Mckee indicates a similar result. 7

\section{Conclusions}

A measurement of the properties of the gasification catalyst itself, lihich has been made for the first time, provides several insights into the mechanism :hich vere not previously obtainable other than as speculation.

The rieasurement of the oxygen activity in the melt systcms demonstratcs that for the $\mathrm{CO}_{2}$ based gasification

a) The nechanisms wich involve the netal or metal cation in a significant lay are insproujate.

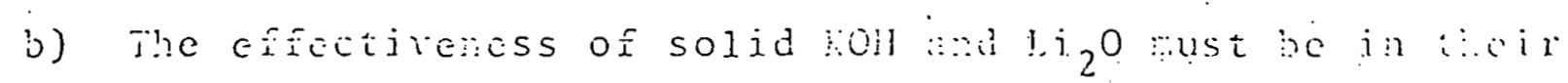
ready conversion to carbonates.

and c) Therefore, the increased activity of $\mathrm{Li}_{2} \mathrm{CO}_{3}$ relative to $\mathrm{K}_{2} \mathrm{CO}_{3}$ is a result of the m.p. being lower periniting more effective dispersion of the catalyst over the carbon surface rather than an intrinsic difference dur to differences between $\mathrm{Li}^{+}$and $\mathrm{K}^{+}$.

It is inieresting to note that in other catalytic systcms in $1:$ hich alkali metal cations have an effect on the catalytic activity of another naterial (e.g: $\mathrm{Li}_{2} \mathrm{~S}_{2} \mathrm{O}_{7}$ is $\mathrm{K}_{2} \mathrm{~S}_{2} \mathrm{O}_{7}$ or $\mathrm{V}_{2} \mathrm{O}_{5}$ for oxidation of benzene to rialejc anhydride ${ }^{8}$ ) the Li salt is typicaliy a poison! 


\section{References}

1. "The Catalyed Gasification Reactions of Carbon," D. W. Mckee GERDL Report 78CRD076, April 1978, pg. 51.

2. "Solid Electrolytes" (Ed. S. Geller), Springer Verlag (1977), pg. 163.

3. "Chemical Reactions in Solvents \& Yiclts," Charlot \& Tremilion (Pergamon Press, 1969), pg. 496.

4. M. Verra \& A. Be11, Fuel 10197 (1978).

5. Ref: 1, pg. 59.

6. Unpublished, quoted by Jalan \&.Rao, Carbon (1978).

7. Ref. 1, pg. 59 .

8. G. H. Tandy, J. Apl. Chon., o $65(1056)$.

9. Sefereses $3, \because 3 \cdot \therefore \div$ 


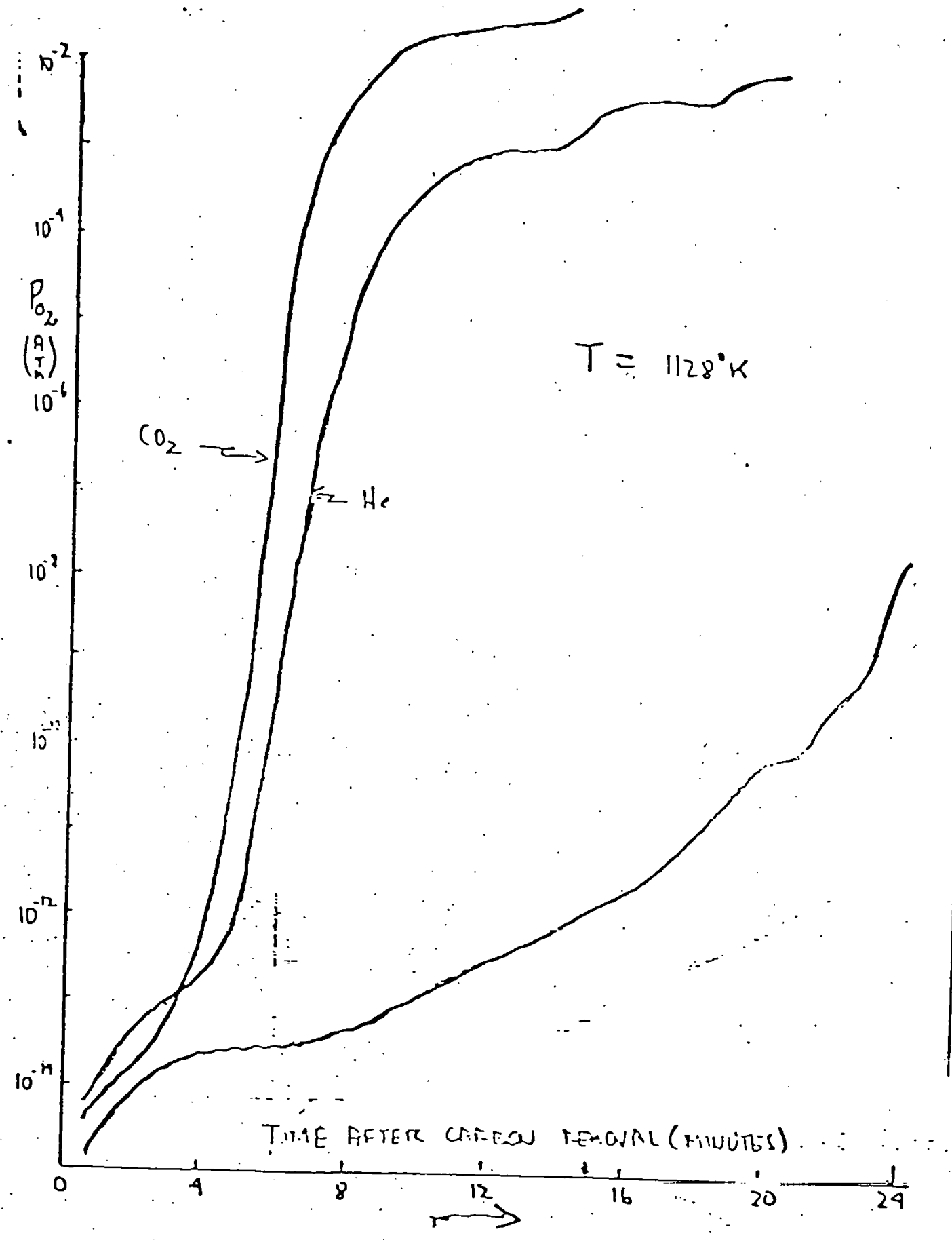

OXYGEN ACTIVITY RECOVERY

figURE 


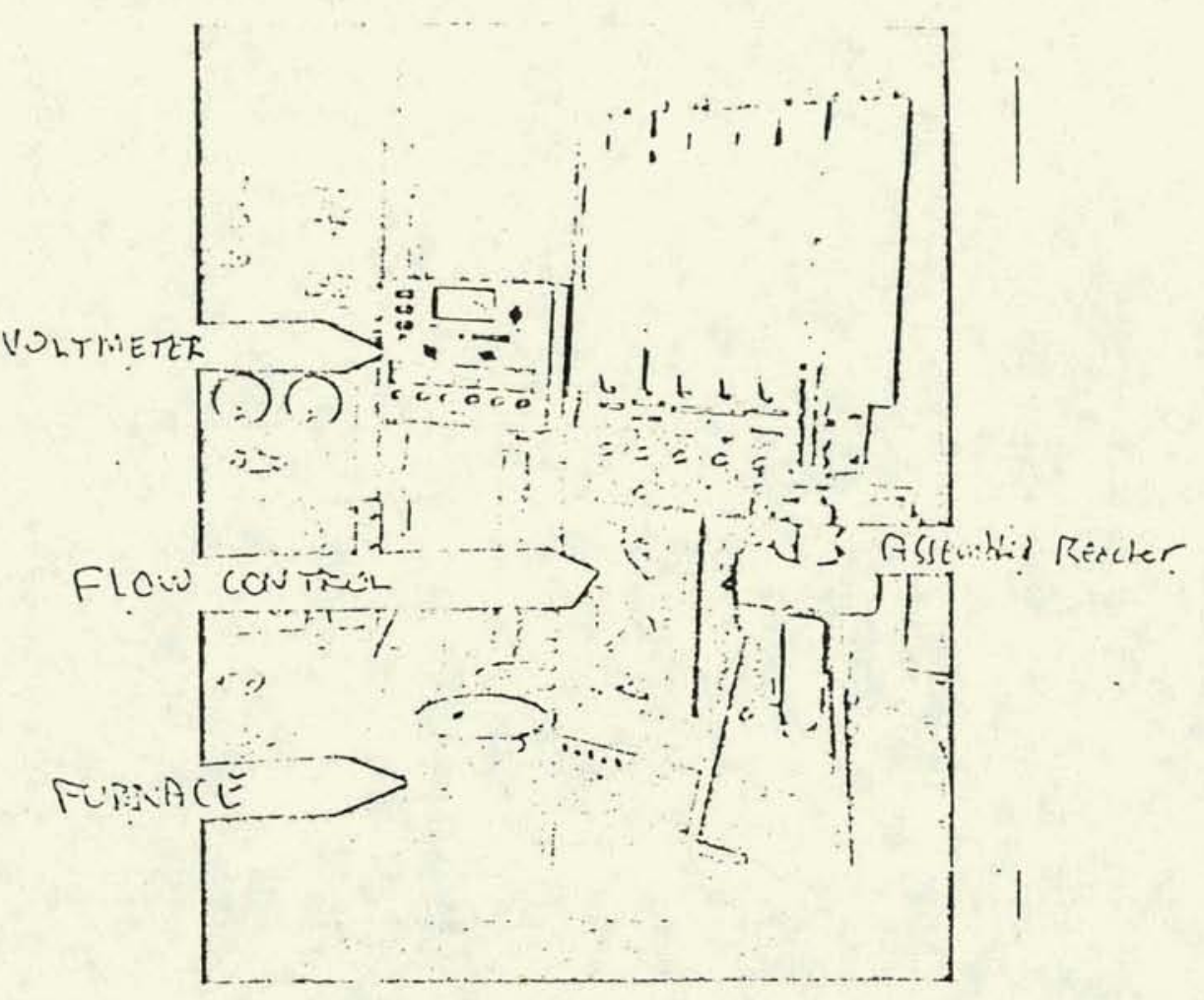

Figuie 3

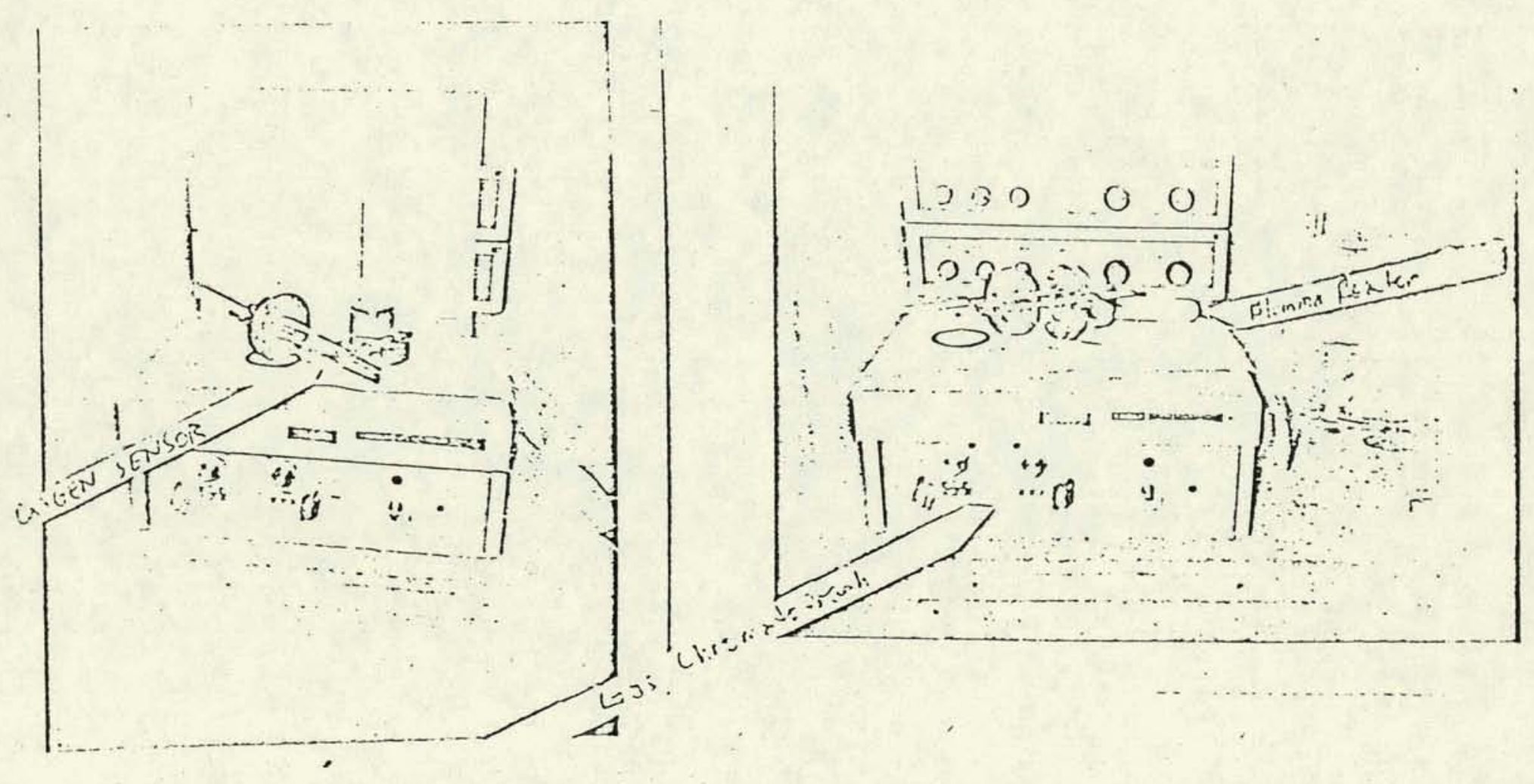

$$
F \because \% ?
$$

